\title{
The chemical composition of silver birch (Betula pendula Roth.) wood in Poland depending on forest stand location and forest habitat type
}

\author{
Hubert Lachowicz • Hanna Wróblewska • Magdalena Sajdak (D) \\ Magdalena Komorowicz $\cdot$ Rafał Wojtan
}

Received: 27 August 2018/Accepted: 31 January 2019/Published online: 22 February 2019

(C) The Author(s) 2019

\begin{abstract}
We report on the most extensive study to date in Poland concerning the variability in the chemical composition of silver birch (Betula pendula Roth.) wood depending on the forest habitat type and the location of the forest stand. The research was carried out in 12 forest districts, on two habitat types where silver birch forest stands predominate in respect of coverage area and merchantable volume. Chemical composition analysis was performed on 51 samples from 306 test trees aged approximately 30, 50 and 70 years. In the examined sample material, the sum of the main chemical components for individual
\end{abstract}

\footnotetext{
H. Lachowicz

Department of Forest Utilization, Warsaw University of Life Sciences (SGGW), Nowoursynowska Str 159, 02-776 Warsaw, Poland

e-mail: hubert.lachowicz@wl.sggw.pl
}

H. Wróblewska · M. Sajdak $(\bowtie) \cdot$ M. Komorowicz Wood Technology Institute, Winiarska Str 1, 60-654 Poznan, Poland e-mail: m_sajdak@itd.poznan.pl

H. Wróblewska

e-mail: h_wroblewska@itd.poznan.pl

M. Komorowicz

e-mail: m_komorowicz@itd.poznan.pl

\section{R. Wojtan}

Laboratory of Dendrometry and Forest Productivity, Warsaw University of Life Sciences (SGGW),

Nowoursynowska Str 159, 02-776 Warsaw, Poland

e-mail: rwojtan@wl.sggw.pl locations varied from 89.26 to $91.57 \%$. The content of substances soluble in water and ethanol ranged from 2.30 to $4.03 \%$, and the ash content was measured at between 0.09 and $0.25 \%$. The results showed that the location had a significant influence on the contents of substances soluble in cold water $(p=0.0015)$, hot water $(p=0.0005)$, ethanol $(p<0.0001)$ and $1 \%$ $\mathrm{NaOH}(p=0.0014)$, as well as on the contents of cellulose $(p=0.04)$, lignin $(p=0.002)$, pentosans $(p=0.04)$ and ash $(p<0.0001)$ and on the $\mathrm{pH}$ value $(p<0.0001)$. Notable influence of location on the contents of secondary constituents of birch wood, especially those extractable with water and ethanol, was recorded for the test plots in north-eastern Poland. The obtained results may form a basis for assessment of the industrial utility of birch wood, as well as the optimisation of traditional methods of utilisation and the development of new such methods that are ecological and sustainable.

Keywords Silver birch - Chemical structure of wood · Cellulose $\cdot$ Lignin $\cdot$ Pentosans $\cdot$ Forest stand locations

\section{Introduction}

In Poland, silver birch (Betula pendula Roth.) is one of the most important forest-forming and timber production deciduous species. It accounts for $7.3 \%$ of Polish 
forest coverage (GUS 2016). According to data from the General Directorate of State Forests, approximately 2.5 million cubic metres of birch wood timber is sourced annually by the State Forests. The constantly increasing share of deciduous species, including silver birch, in the stand composition of Polish and European forests is leading to a greater supply of timber from those species (GUS 2016; Ozolinčius et al. 2016).

Traditionally, birch wood is used in large amounts by industries such as pulp and paper, particle board, plywood, sawmill, furniture, and also as a firewood. The pharmaceutical, cosmetics and food industries use birch leaves, bark and sap for the production of herbal medicines, antioxidants, cosmetics, dietary supplements and drinks (Karnaouri et al. 2016; KociołekBalawejder and Żebrowska 2009; Ozolinčius et al. 2016). However, the above-mentioned uses of birch wood do not fully exploit its potential as a renewable material.

Obtaining materials and energy from renewable sources, including forest biomass, is becoming a priority due to the depletion of fossil fuels, especially crude oil. Energy sources and chemical products of high added value can be expected to be produced by thermal or chemical biomass processing techniques such as torrefaction, pyrolysis, hydrolysis, refining, dehydration and extraction, from so far undervalued materials like bark or waste sawdust. The wood and bark of silver birch, together with other deciduous species, are examples of valuable biomass resources being extensively studied with regard to their use on an industrial scale (Bergström and Matisons 2014; Clark and Deswarte 2008; Hansen et al. 2012; Ibrahim et al. 2013; Karnaouri et al. 2016; Pinto et al. 2009; Testova et al. 2009; Turley et al. 2006; Vedrenikovs et al. 2010; Zhurinsh et al. 2013).

The main factors that determine wood industrial utility are the anatomical and chemical structure. Birch wood consists of wood fibres, vessels, medullary rays and parenchyma. The contributions of particular elements vary within a single tree, and they depend not only on the species, age and location, but also on the habitat conditions (Braun 1963; Hall 1952; Süss 1967; Süss and Müller-Stoll 1969). Wood fibres are the main component, accounting on average for $64.8 \%$ of the silver birch wood's mass (Huber and Prütz 1938; Wagenführ and Scheiber 2007).
The high content of wood fibres and the relatively high density and favourable chemical composition of birch wood make it a good raw material for the pulp and paper industry (Surewicz 1972). A disadvantage of this wood is that it contains between 2.5 and $3 \%$ of extractive substances with up to $33 \%$ unsaponifiable components, being resistant to chemicals (Hillis 1962). These substances cause difficulties during the bleaching of the cellulose pulp obtained from birch wood.

The core components of wood are natural biopolymers such as cellulose, hemicelluloses (polysaccharides) and lignin. These are supplemented with other constituents such as proteins, starch, substances soluble in organic solvents (extractives) and in water, and mineral substances. Cellulose is a linear polysaccharide with a crystal structure composed of linear chains of D-glucose linked by ß-1,4-glycosidic bonds. Hemicelluloses are polysaccharides that differ from cellulose in their composition and structure. They are a combination of pentoses and hexoses (xylose, arabinose, mannose, galactose and glucose) with acetyl groups, uronic acid and 4- $O$-methylethers. Lignin is an amorphous natural polymer with a complex structure, mainly consisting of three phenylpropane monomers: p-hydroxyphenyl, guaiacyl and syringyl. Guaiacyl dominates in the wood of coniferous tree species, and syringyl and guaiacyl dominate in deciduous wood. The extractives are a group of compounds that includes fats, fatty acids, alcohols, phenols, terpenes, steroids, resins, resin acids, waxes, wood gums, etc. Substances soluble in water include sugars, mineral salts, tannins, dyes, pectins, free acids and others (Fengel and Wegener 1989; Han and Rowell 1997; Pettersen 1984; Prosiński 1984; Yang and Jaakkola 2011).

The results of studies concerning the chemical composition of various birch species have been published over many years in scientific papers, monographs and atlases. The findings vary depending on the research methods employed and the birch species studied, as well as the examined tree part (trunk, branches, bark, pathological growths, reaction wood), tree age and climate conditions (Fengel and Grosser 1975; Fengel and Wegener 1989; Galewski and Korzeniowski 1958; Gustafsson et al. 1952; Krutul et al. 2011; Nikitin 1962; Pettersen 1984; Prosiński 1984; Surmiński 1964, 1979, 2010; Wagenführ and Scheiber 2007; Wang et al. 2018; 
Wróblewska and Zieliński 1994; Yang and Jaakkola 2011). Often the results are incomplete and obtained by different analytical procedures and sometimes they are from samples originating from a single tree and mostly of unknown origin. Surmiński (1979) comparing silver birch and downy birch, on the basis of his own and several authors investigations, revealed that the chemical composition of silver birch wood and downy birch wood sometimes displays larger differences within the same species than between different birch species. This variation can be assumed to be linked to the different geographical regions from which the wood originates, the age of the trees and the height of trunk from which samples are taken. According to this author small differences are of little consequence for the industrial usage of birch wood.

Despite the great range of silver birch (B. pendula Roth.) in Europe and Asia, the literature does not provide comprehensive data concerning the chemical composition of this species especially based on big representative sample analysis. Therefore, there is a great need to carry out an extensive research on birch wood chemical structure (using uniform analytical procedures) considering certain important features of forest cultivation. Additionally, when studying the chemical composition of various lignocellulosic materials, including all wood species, it is very important to use precisely described analytical procedures that allow for the comparison of results and their statistical analysis (Rabemanolontsoa and Saka 2013).

Determination of differences in the chemical composition of $B$. pendula Roth. depending on growth and development conditions, will facilitate traditional as well as innovative use of this wood. The Department of Forest Utilisation at Warsaw University of Life Sciences for many years has been conducting studies using a uniform methodology. It aims to develop a forest map of Poland with information on variation in the technical quality of wood from the main forestforming tree species. Extensive research has recently been carried out on silver birch wood, concerning the wood's anatomy, structure, physical and mechanical characteristics, and also its chemical composition. The research has considered the geographical location, tree age, forest habitat type, and the thickness of the tree (Lachowicz 2010a, b, 2011a, b, 2015; Lachowicz and Paschalis-Jakubowicz 2011; Lachowicz et al. 2018a). Obtained results indicated significant influence of the analysed factors on the majority of physical and mechanical properties of birch wood. The influence of location and forest habitat type on the fuel properties of birch raw material was also demonstrated, except for the influence of forest habitat type on the content of elements: carbon $(\mathrm{C})$, hydrogen $(\mathrm{H})$, nitrogen $(\mathrm{N})$ and chlorine (Cl) (Lachowicz et al. 2018b).

In the current study analyses of the chemical structure of silver birch wood were conducted in cooperation with the Institute of Wood Technology in Poznan. This is the first time that extensive research concerning the chemical characteristics of silver birch wood has been carried out in Poland. What differs this study from other is the dimension-a comprehensive analysis of chemical composition of birch wood samples from all main locations and dominating forest habitat types of this species covering a huge area of Poland and the number of samples gathered allowing to carry out statistical analysis.

Recognition of birch wood in raw material bases is of important value because there is an increase in the demand for this raw material in the central part of Europe and Russia. This tendency results from the higher need for wood for the pulp, paper and plywood industries as well as for a special type of fibres used in the production of products characterized by exceptional strength (i.e. products from polymers) or textiles with particular insulating properties (Lachowicz et al. 2016). Therefore full, comprehensive understanding of birch wood chemical composition can influence new application ways, or the use of new technologies for its processing.

The aim of this study was to examine the variation of certain selected elements of the chemical structure of silver birch wood depending on test plot location (the geographical location of the forest stands) and the forest habitat type.

A hypothesis was put forward: the geographical location of the trees from which the material for the research was taken as well as the forest habitat type have a significant impact on the content of the individual constituents of the chemical structure of Betula pendula Roth. wood in Poland. 


\section{Materials and methods}

Field study

The study was conducted on forest stands under the administration of the State Forests National Forest Holding (PGL LP). Test plots were chosen based on tables of area and merchantable volume (dated 1 January 2012) and on the geographical distribution of forest districts in the principal resource bases of birch in fresh broadleaved forest (FBF) and fresh mixed broadleaved forest (FMBF) habitats. These are the two types of habitat in Poland where birch forest stands dominate in size and volume. More information on the analysed forest habitat types can be found in Lachowicz et al. (2018b).

The field research was conducted in 12 forest districts, all located in different national resource bases for birch. In all districts, test plots were established on habitats of FBF type. In five selected forest districts, additional test plots were established on habitats of FMBF type to benchmark comparisons between FBF and FMBF forest habitats. As a result, 17 test plots were established (12 on FBF and 5 on FMBF) located in the following districts: Płońsk (FBF), Sokołów (FBF), Biała Podlaska (FBF), Płaska (FBF), Giżycko (FBF and FMBF), Górowo Iławeckie (FBF), Elbląg (FBF), Mircze (FBF), Bobolice (FBF and FMBF), Łobez (FBF and FMBF), Lipinki (FBF and FMBF), Rudziniec (FBF and FMBF). The arrangement of the test plots was done according to the geographical location of resource bases. From Płońsk, throughout Sokołów, Biała Podlaska, Płaska, Giżycko, Górowo and Elbląg to Mircze are the northeastern (N-E), Bobolice and Łobez north-western (N$\mathrm{W})$, Lipinki south-western (S-W) and Rudziniec south (S) resource base (Figs. 1, 2, 3, 4, 5, 6, 7, 8, 9, and 10). The locations of the forest districts where the test plots were established are shown in Fig. 1. In each of the 17 locations, test plots were established in three age categories (approximately 30, 50 and 70 years), thus giving 51 test variations.

Sampling and analysis

On all test plots (51 variations) breast height diameters were measured for all trees for which the diameter was greater than $7 \mathrm{~cm}$ (Wolski 1969). The sample trees in the test plots were chosen using Hartig's method based on the mean BHD with three thickness classes (Grochowski 1973): class 1 containing the thinnest trees, class 2 containing trees of average thickness, and class 3 consisting of the thickest trees.

From each thickness class, two trees were selected and felled, making six trees from each sample plot. In total, sample materials were collected from 306 trees. Two or three 50-centimetre-long trunk sections were cut out (below the $1.3 \mathrm{~m}$ height point and $50-100 \mathrm{~cm}$ above it) and appropriately labelled. Next, the wood was debarked and split open in order to increase the uniformity of drying and to avoid doatiness. Wood from the internal part of the split log was cut out so that the test samples could be obtained from the outside part of the trunk. At the same time, the material was sorted in order to eliminate split logs with such defects as knots, construction defects or colouring. After a few months of seasoning, samples were taken for analysis of the chemical characteristics. Each sample (51 samples in total) consisted of representative material collected from six trees in different thickness classes. The material was ground in a Pulverisette 15 (Fritsch, Germany) cutting mill and sifted to the desired granulation using an Analysette 18 analytical sieve shaker (Fritsch, Germany). For the chemical structure analyses, sawdust with a grain size between 0.5 and $1.0 \mathrm{~mm}$ was used and for $\mathrm{pH}$ determination grain size between 0.25 and $0.5 \mathrm{~mm}$ was used. Chemical composition of birch wood was determined with the use of classical test methods (Browning 1967; Prosiński 1984; TAPPI 1996-1997) and pH was determined by Gray's method (Gray 1958).

The following characteristics and constituents of birch wood were determined:

- moisture content-using the drying-weight method at a temperature of $(103 \pm 2){ }^{\circ} \mathrm{C}$

- content of substances soluble in cold water

- content of substances soluble in hot water

- content of extractives soluble in ethanol

- content of substances soluble in $1 \% \mathrm{NaOH}$

- cellulose content-using Seifert's method

- Klason lignin content (insoluble in $72 \%$ sulphuric acid)—using the Tappi method

- content of sulphuric acid soluble lignin-with the spectrophotometric method in UV light (wavelength $205 \mathrm{~nm}$ ) using a UNICAM UV/VIS model UV2 spectrometer (UK)

- pentosans content-using the Tollens method 
Fig. 1 Geographical distribution of the national forest districts where test plots were located (Lachowicz 2015)
Fig. 2 Average contents of cold water soluble substances in silver birch wood depending on test plot location
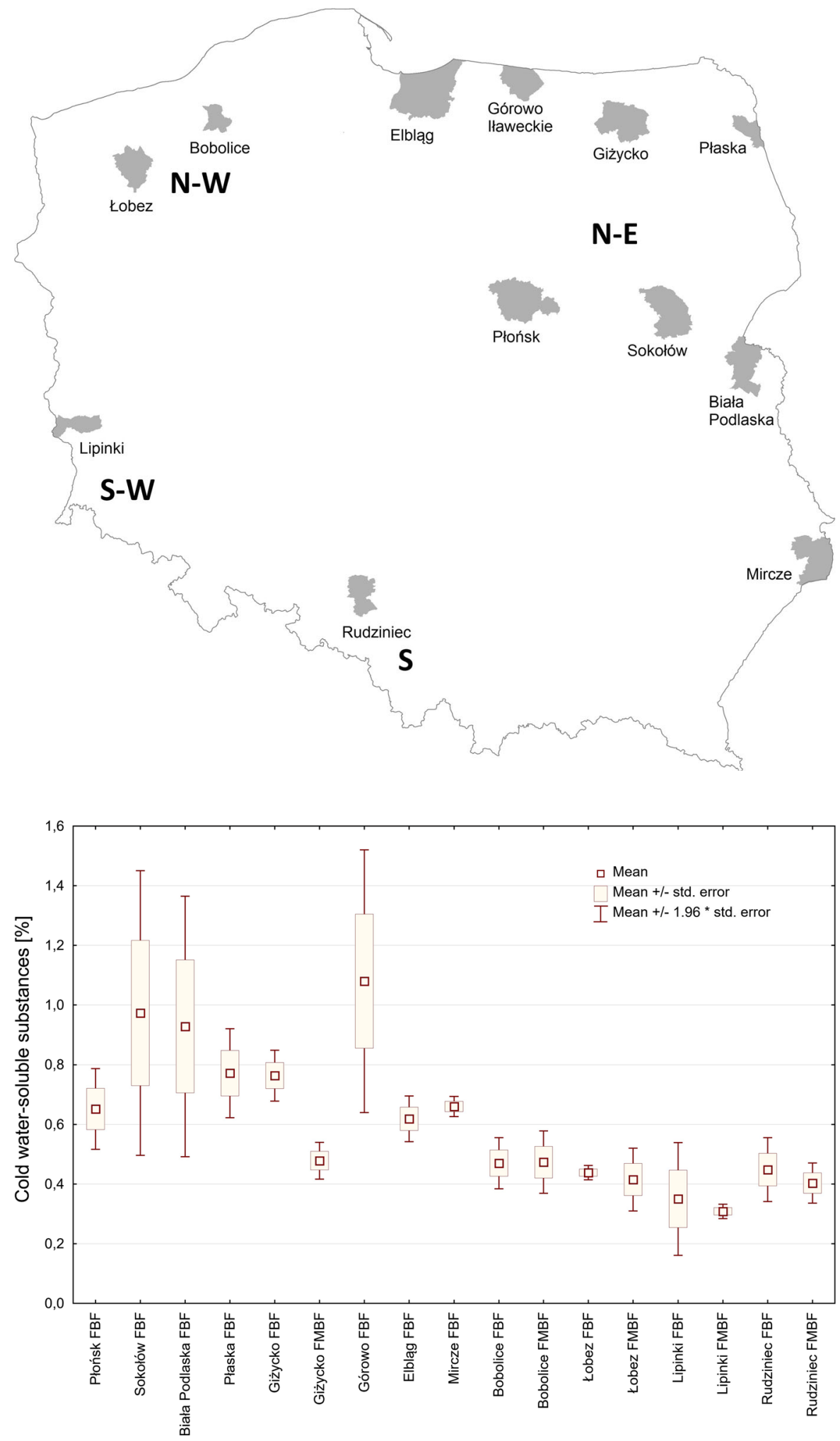
Fig. 3 Average contents of hot water soluble substances in silver birch wood depending on test plot location

Fig. 4 Average contents of ethanol-soluble substances in silver birch wood depending on test plot location
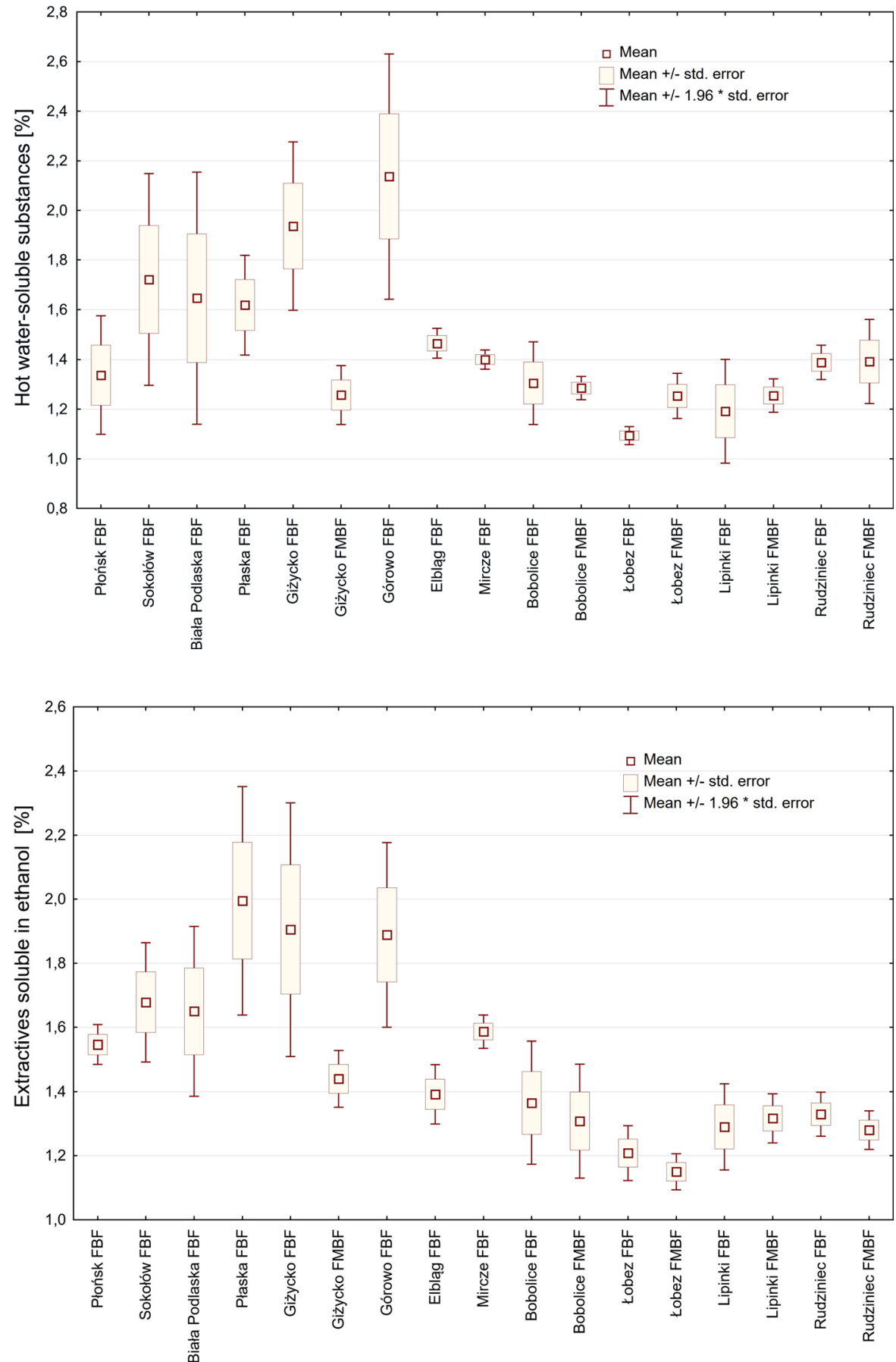

- ash content (mineral substances) at temperature of $(575 \pm 25){ }^{\circ} \mathrm{C}$

- wood $\mathrm{pH}$-using an ORION 900A pH meter (USA) with $\mathrm{Ag} / \mathrm{AgCl}$ ORION Triode model 91-57 BIN.
Analyses were performed in two replications. The results were expressed as percentages of oven dry wood, or in the case of cellulose, pentosans and lignin as percentages of oven dry extracted wood. 
Fig. 5 Average contents of substances soluble in $1 \%$ $\mathrm{NaOH}$ in silver birch wood depending on test plot location

Fig. 6 Average cellulose content in silver birch wood depending on test plot location
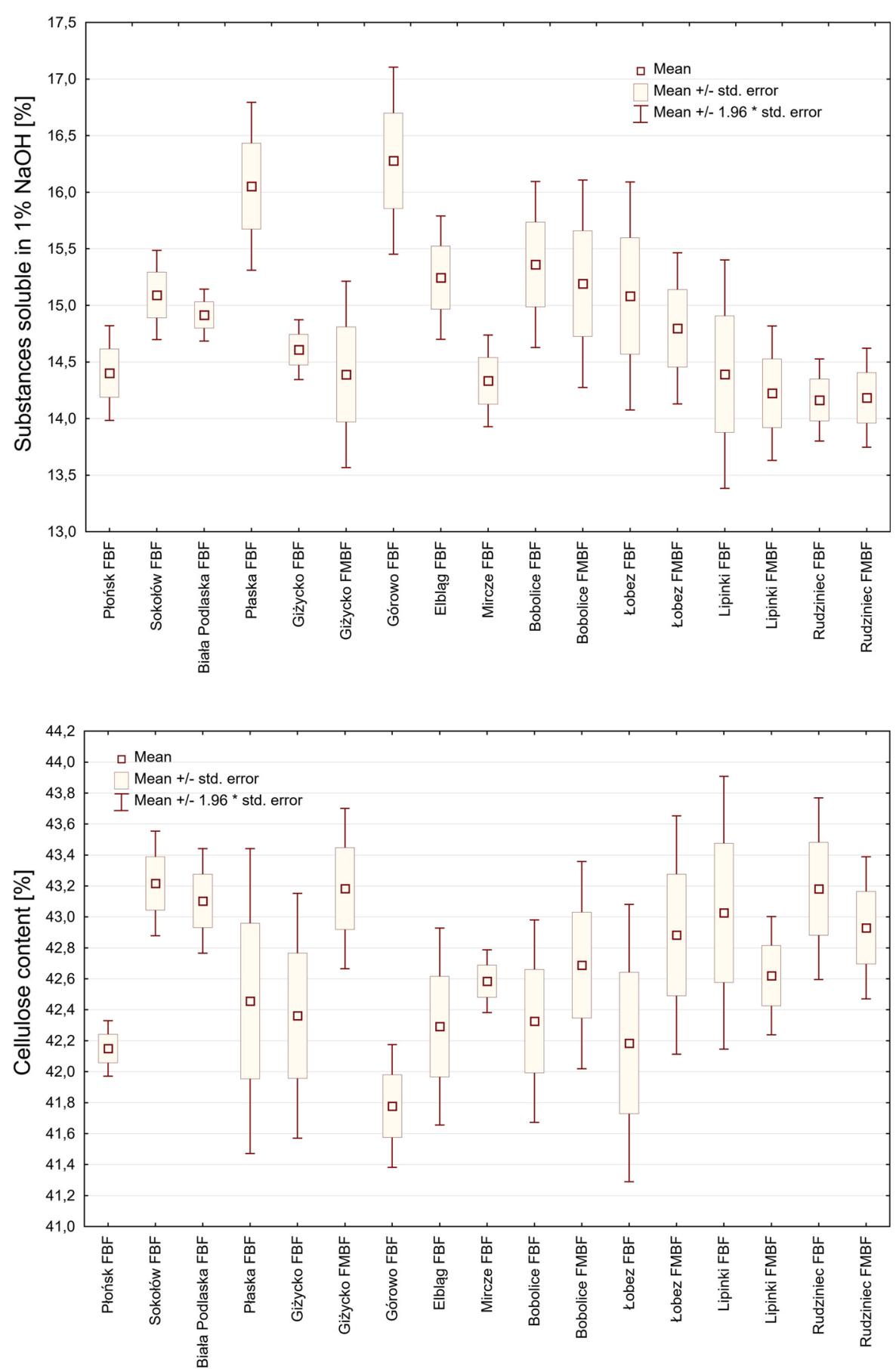

Statistical analysis

The influence of test plot location on the values of the selected characteristics was analysed using the Kruskal-Wallis test, which is a nonparametric alternative to analysis of variance. This method was chosen because the data did not meet the homogeneity of variance criterion (result of Leven's test $p<0.001$ ) and in some of the analysed groups the distribution of the variables deviated from a normal distribution. When statistically significant differences were found between the analysed categories, a multiple range rank 
Fig. 7 Average combined contents of acid-soluble and insoluble lignin in silver birch wood depending on test plot location

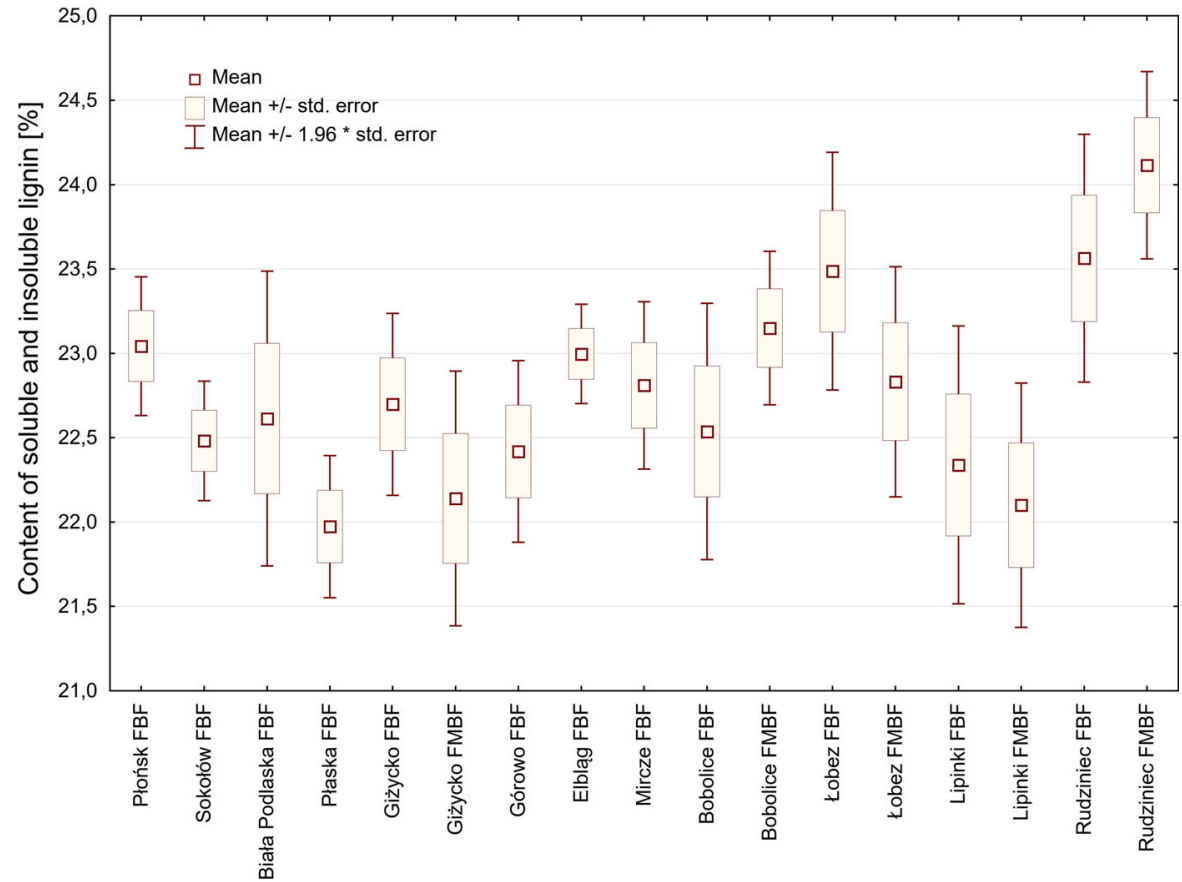

Fig. 8 Average pentosans content in silver birch wood depending on test plot location

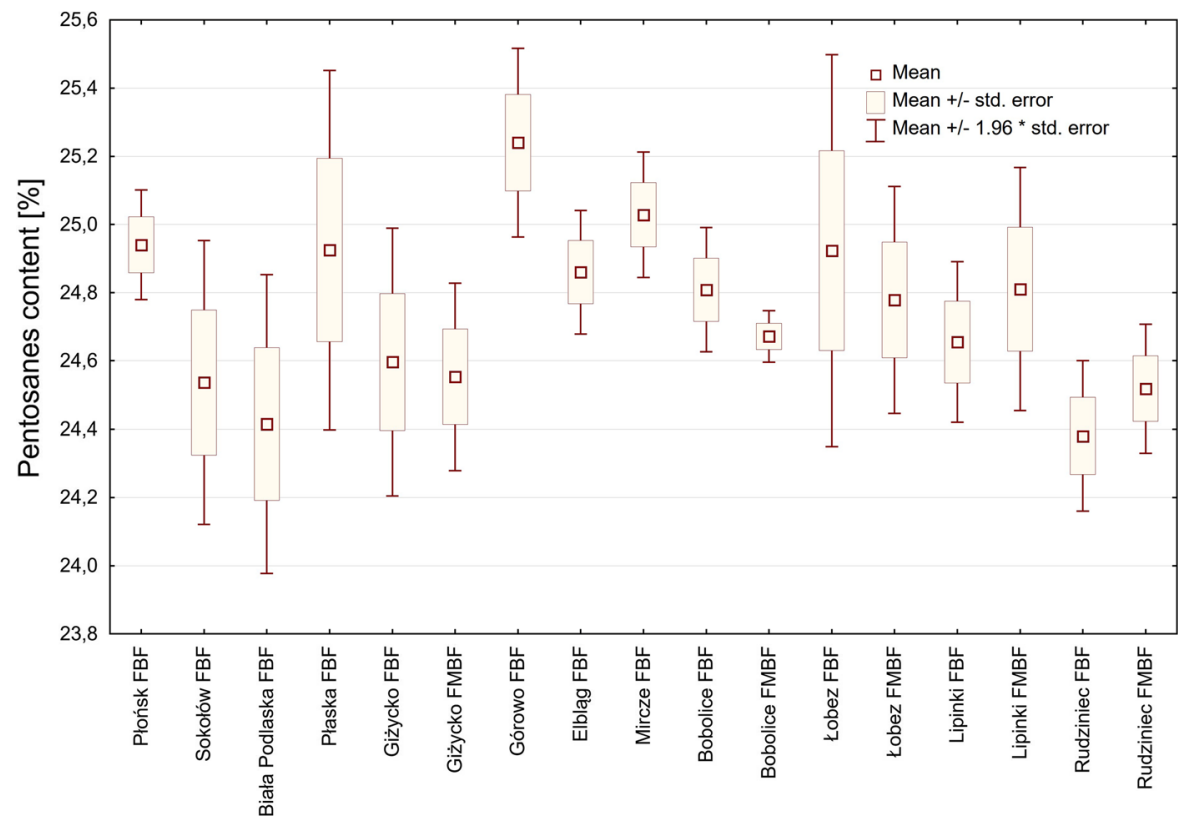

test was performed to identify groups having similar values of the analysed characteristics.

On the portion of data representing five forestry districts (Giżycko, Bobolice, Łobez, Lipinki and Rudziniec), correlations between values of the studied characteristics and the forest habitat type (for two groups) were analysed. Because of the strong asymmetry of the distribution of the variables, a Mann-Whitney test was applied; this is a nonparametric alternative to the $t$ test (Bruchwald 1989; Kala 2009).

Additionally, to identify locations characterised by similar average values relating to the chemical structure of the wood, a cluster analysis was carried out. 
Fig. 9 Average ash content in silver birch wood depending on test plot location

Fig. 10 Average acidity of silver birch wood depending on test plot location
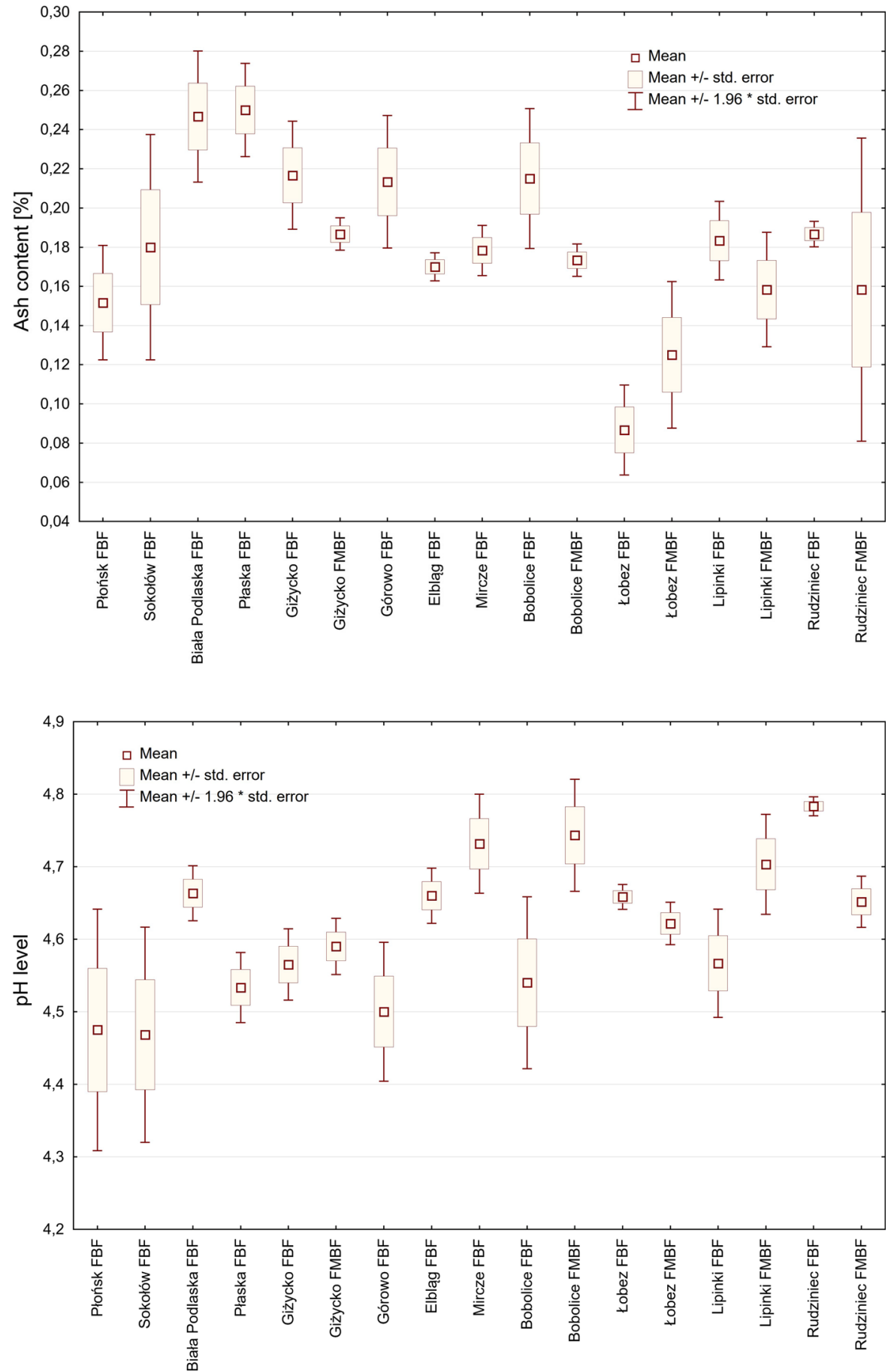

Cluster analysis is a multivariate method which aims to classify a sample of subjects (or objects) based on a set of measured variables into many diverse groups so that similar subjects are placed in the same group. A hierarchical agglomerative method was applied, using
Euclidean distances. Grouping of objects was performed using the Ward method, in which the objective is to obtain the smallest variance of the distance within a cluster (Murtagh and Legendre 2014). 


\section{Results}

Each test plot was represented by three samples of wood obtained from trees of different age (approx. 30, 50 and 70 years). In order to show correlations between the location and forest habitat type and the chemical composition of silver birch wood, the results obtained from each test plot were averaged. Each average value was calculated from six primary results. The results for the average contents of individual components of silver birch wood for 17 test plots are shown in Figs. 2, 3, 4, 5, 6, 7, 8, 9, 10 and Table 1.

The moisture content of the examined samples in dry state after grinding to the required grain size ranged from 6.08 to $9.94 \%$, and the average moisture content for all 51 examined wood samples was $7.65 \%$.

Contents of substances soluble in water, ethanol and $1 \% \mathrm{NaOH}$

The lowest average content of cold water soluble substances $(0.31 \%)$ was recorded in the wood of birch from the Lipinki forest district (FMBF), and the highest (1.08\%) in wood from the Górowo Iławeckie district (FBF). The average content of substances soluble in cold water for all tested material from the FBF forest habitat type was $0.68 \%$. For the five locations where the content of the examined substances was compared based on the forest habitat type, a value of $0.49 \%$ was obtained for the FBF habitat, slightly higher than the value of $0.42 \%$ obtained for the FMBF habitat. The average content of cold water soluble substances in the entire set of analysed material was $0.60 \%$, with the values obtained for individual samples ranging from 0.13 to $1.82 \%$.
Higher values of the content of cold water soluble substances were recorded in the samples originating from birch resource bases in north-eastern part of Poland.

The location of the test plots was shown to have a statistically significant influence $(p=0.0015)$ on the content of cold water soluble substances in birch wood (Fig. 2). There were statistically significant differences for data from the Lipinki forest district (FBF) in comparison with data from the Giżycko (FBF) and Górowo Iławeckie (FBF) districts. No statistically significant differences were found $(p=0.07)$ between contents of cold water soluble substances in birch wood depending on the forest habitat type.

The lowest average value $(1.09 \%)$ of the content of hot water soluble substances depending on location was recorded in the Łobez forest district (FBF), and the highest $(2.14 \%)$ in Górowo Iławeckie (FBF). The average content of substances soluble in hot water for all tested material from the FBF forest habitat type was $1.52 \%$. The value for FBF in the five locations where habitat types were compared $(1.38 \%)$ was slightly higher than the value for FMBF (1.29\%). The average content of hot water soluble substances in silver birch wood for the entire set of analysed material was $1.45 \%$, with the values obtained for individual samples ranging from 0.84 to $2.77 \%$.

Higher values of the content of hot water soluble substances were recorded in the samples originating from birch resource bases in north-eastern part of Poland.

Test plot location was found to have a statistically significant influence $(p=0.0005)$ on the content of hot water soluble substances in birch wood (Fig. 3). There were statistically significant differences in data from the Łobez forest district (FBF) in comparison with
Table 1 The average results of silver birch wood chemical composition from 17 test plots in Poland

\begin{tabular}{lrccl}
\hline Wood components & Mean & Minimum & Maximum & Standard deviation \\
\hline Substances soluble in cold water & 0.60 & 0.13 & 1.82 & 0.33 \\
Substances soluble in hot water & 1.45 & 0.84 & 2.77 & 0.39 \\
Substances soluble in ethanol & 1.49 & 1.07 & 2.61 & 0.33 \\
Substances soluble in 1\% NaOH & 14.87 & 12.81 & 17.62 & 0.974 \\
Cellulose & 42.65 & 40.76 & 44.15 & 0.822 \\
Lignin (acid insoluble with acid soluble) & 22.78 & 20.67 & 25.20 & 0.901 \\
Pentosans & 24.74 & 23.67 & 25.81 & 0.435 \\
Mineral substances (ash) & 0.18 & 0.03 & 0.29 & 0.05 \\
pH & 4.62 & 4.19 & 4.89 & 0.13 \\
\hline
\end{tabular}


data from the Giżycko (FBF) and Górowo Iławeckie (FBF) districts. No statistically significant differences were found $(p=0.58)$ between the contents of hot water soluble substances in birch wood depending on the forest habitat type.

The content of ethanol-soluble substances in birch wood took the lowest average value $(1.15 \%)$ in the district of Łobez (FBF), and the highest (1.99\%) in the Płaska (FBF) district. The average content of substances soluble in ethanol for all tested material from the FBF forest habitat type was $1.57 \%$. For the five locations where habitat types were compared, the value for $\mathrm{FBF}$ was $1.42 \%$, slightly higher than the value for FMBF (1.30\%). The content of ethanolsoluble substances in individual samples ranged between 1.07 and $2.61 \%$. The average content of ethanol-soluble substances in silver birch wood for the entire set of analysed material was $1.49 \%$.

Higher values of the content of ethanol-soluble substances were recorded in the samples originating from birch resources located in north-eastern part of Poland.

Test plot location was found to have a statistically significant influence $(p=0.0001)$ on the content of ethanol-soluble substances in birch wood (Fig. 4). There were statistically significant differences in data from the forest district of Łobez (FBF and FMBF) in comparison with data from the Płaska (FBF), Giżycko (FBF) and Górowo Iławeckie (FBF) districts. No statistically significant differences were found ( $p=0.27$ ) between contents of ethanol-soluble extractives in birch wood depending on the forest habitat type.

The analysis of the influence of location on the content of substances soluble in $1 \%$ aqueous $\mathrm{NaOH}$ solution showed that the lowest average content of these substances $(14.16 \%)$ occurred in wood from the Rudziniec forest district (FBF), and the highest $(16.28 \%)$ in wood from Górowo Iławeckie (FBF). The average content of these substances for all tested material from the FBF forest habitat type was $14.99 \%$. The value for FBF in the five locations where habitat types were compared was $14.72 \%$, slightly higher than the value for FMBF (14.56\%). The average content of substances soluble in $1 \% \mathrm{NaOH}$ in the entire set of analysed material was $14.87 \%$, with values for individual samples ranging from 12.81 to $17.62 \%$.

The lowest contents of $1 \% \mathrm{NaOH}$-soluble substances were recorded in the samples from birch resource bases in southern regions-south and southwestern part of Poland.

Test plot location was found to have a statistically significant influence $(p=0.0014)$ on the content of substances soluble in $1 \% \mathrm{NaOH}$ (Fig. 5). Statistically significant differences in the content of these substances were recorded between the Rudziniec (FBF) and Górowo Iławeckie (FBF) districts. No statistically significant differences were found $(p=0.74)$ between contents of substances soluble in $1 \% \mathrm{NaOH}$ in birch wood depending on forest habitat type.

Contents of primary chemical components

The lowest average content of Seifert cellulose in silver birch wood $(41.78 \%)$ was recorded in the Górowo Iławeckie (FBF) forest district and the highest $(43.22 \%)$ in the Sokołów (FBF) district. The average content of cellulose for all material from the FBF forest habitat type was $42.56 \%$. The average value for FBF in the five locations where habitat types were compared was $42.62 \%$, slightly lower than the value for FMBF (42.86\%). The average cellulose content in the entire analysed set of silver birch wood was $42.65 \%$, with individual sample values ranging from 40.76 to $44.15 \%$.

The statistically significant influence of the location of the test plots $(p=0.04)$ on the cellulose content in birch wood is shown in Fig. 6. The multiple range rank test did not show statistically significant differences between groups. No statistically significant differences were discovered $(p=0.44)$ between values of cellulose content depending on the forest habitat type.

The lowest average value of the combined content of lignin (both types: acid-insoluble and acid-soluble) in birch wood $(21.97 \%)$ was recorded in the forest district of Płaska (FBF), and the highest (24.12\%) in the Rudziniec (FMBF) district. The average lignin content for all tested material from the fresh broadleaved forest habitat type was $22.75 \%$. For the five locations containing both FBF and FMBF habitats, the lignin content differed slightly between the habitat types, amounting to $22.92 \%$ and $22.87 \%$ respectively. The average value of the combined content of soluble and insoluble lignin in birch wood for the entire set of analysed material was $22.78 \%$, with individual test values ranging from a minimum of $20.67 \%$ to a maximum of $25.20 \%$. 
It was shown that the influence of test plot location on the combined content of acid-soluble and insoluble lignin is statistically significant $(p=0.002)$ (Fig. 7). Statistically significant differences were found only between samples from Płaska (FBF) and Rudziniec (FMBF). No statistically significant differences in lignin content in birch wood were found between forest habitat types $(p=0.62)$.

Analysis of the influence of location on the content of pentosans in birch wood showed that, on average, the lowest pentosans content is found in wood from the Rudziniec (FBF) forest district $(24.38 \%)$ and the highest in wood from the Górowo Iławeckie (FBF) district $(25.24 \%)$.

The average content of pentosans in all tested material from the FBF forest habitat type was $24.78 \%$. At the five locations where habitat types were compared, the values for FBF and FMBF were identical $(24.67 \%$ for both). The overall average content of pentosans in silver birch wood was $24.74 \%$ with a minimum value of $23.67 \%$ and a maximum of $25.81 \%$ obtained for individual samples.

The statistically significant influence $(p=0.04)$ of the location of the test plots on the pentosans content in birch wood is shown in Fig. 8. Statistically significant differences were found between samples from the districts of Rudziniec (FBF) and Górowo Iławeckie (FBF).

Statistically significant differences were not found ( $p=0.96)$ in the pentosans content in birch wood originating from different forest habitat types.

\section{Ash content}

The lowest average ash content $(0.09 \%)$ was recorded in the Łobez (FBF) forest district, and the highest $(0.25 \%)$ in the districts of Biała Podlaska (FBF) and Płaska (FBF). The average ash content for all material from the FBF forest habitat type was $0.19 \%$. The average value for FBF in the five locations with both habitat types was $0.18 \%$, slightly higher than the value for FMBF $(0.16 \%)$. The average ash content in the entire analysed set of material was $0.18 \%$, with a minimum of $0.03 \%$ and a maximum of $0.29 \%$.

The content of ash (mineral substances) was higher in wood from the birch resource bases in north-eastern part of Poland.

Results from Łobez (FBF and FMBF) and from Biała Podlaska (FBF), Płaska (FBF) and Giżycko
(FBF) clearly show that the location of the test plot has a statistically significant influence $(p<0.0001)$ on the ash content in birch wood (Fig. 9). No statistically significant differences were found $(p=0.19)$ in the ash content depending on the forest habitat type.

Values of $\mathrm{pH}$

The lowest average $\mathrm{pH}$ value in birch wood (4.47) was measured in the forest districts of Płońsk (FBF) and Sokołów (FBF), and the highest (4.78) in Rudziniec (FBF). The average $\mathrm{pH}$ for all material from the FBF forest habitat type was 4.60. For the five locations containing both forest habitat types, the average $\mathrm{pH}$ for FBF was 4.62, slightly lower than the value for the FMBF habitat type (4.66). The average $\mathrm{pH}$ of silver birch wood for the entire set of analysed material was 4.62, with individual values ranging from 4.19 to 4.89 .

Even though the differences in $\mathrm{pH}$ levels in the tested samples were only slight, they turned out to be statistically significant $(p<0.0001)$ (Fig. 10). Statistically significant differences in the $\mathrm{pH}$ level were observed between wood from Rudziniec (FBF) and Sokołów (FBF), Płaska (FBF), Giżycko (FBF) and Górowo Iławeckie (FBF).

No statistically significant differences $(p=0.38)$ were found in $\mathrm{pH}$ levels depending on the forest habitat type.

\section{Cluster analysis}

A cluster analysis performed for the test plots, based on the average values of elements that characterise the chemical composition of wood, showed a wide variation of results for individual locations (Fig. 11).

The identified clusters do not form groups that can be distinguished on the basis of geographical location. The wide variation of results concerning the chemical characteristics of birch wood may arise from the fact that the analysed parameters are largely dependent on the local growing conditions, and especially on soil composition.

\section{Discussion}

Similar observations were made by a team led by Prosiński et al. (1955) in studies concerning the influence of the location of spruce forest stands, 
Fig. 11 Results of clustering of test plots based on content values characterising the chemical composition of birch wood

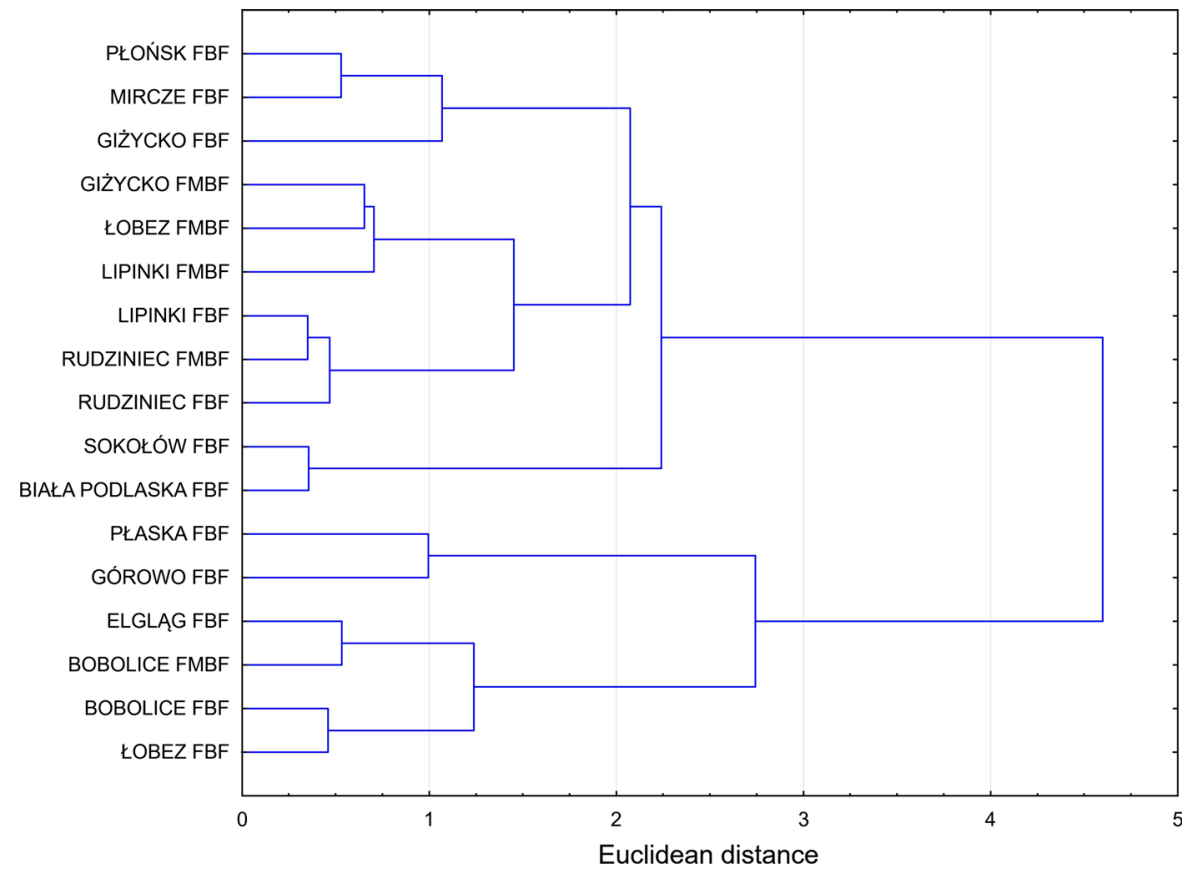

between the northern State Forest regions of Olsztyn and Białystok and the southern regions of Poznań and Kraków, on the chemical composition of the wood. Samples for testing were obtained from spruce trees growing in different forest habitats, at 2 and $10 \mathrm{~m}$ above ground. The studies showed higher contents of cellulose and lignin in trees from the northern regions of Poland. However, the location was not found to have a significant influence on the remaining constituents of spruce wood.

The results concerning the content of constituents in the chemical composition of silver birch (Betula pendula Roth.) wood from different locations and from two different forest habitat types (FBF and FMBF) obtained in the present study were compared with data available from the literature.

Räisänen and Athanassiadis (2013), using data drawn from the literature (27 works in total published between 1978 and 2011, including 13 works published since 2000), compiled figures for the chemical composition of wood, bark from the stem, branches, foliage (needles and leaves), stumps and roots of Scots pine, Norway spruce, and silver and downy birch (combined figures were given for the two birches). They reported average (median) values for the contents of cellulose, hemicelluloses, lignin and extractives using the percentages obtained from the analysed publications. For birch trunk wood ( $B$. pendula and $B$. pubescens) the calculated contents were $43.9 \%$ for cellulose, $28.9 \%$ for hemicelluloses, $20.2 \%$ for lignin and $3.8 \%$ for extractives (Räisänen and Athanassiadis 2013).

A more detailed chemical composition of silver birch (Betula pendula Roth.) wood was provided by Galewski and Korzeniowski (1958), Surmiński (1964, 2010), Wagenführ and Scheiber (2007), Wróblewska and Zieliński (1994), Wang et al. (2018) and Fengel and Wegener (1989) (Table 2). Pettersen (1984) included birch species in his comprehensive overview of the chemical compositions of deciduous and coniferous trees in several countries and continents, although no data was given for Betula pendula Roth. (Table 3). Also Fengel and Wegener (1989) reported the chemical composition of a birch species referring to geographical location.

The variation in cellulose levels clearly reflects the different methods used for its determination. The highest values are obtained with the Cross-Bevan method, medium values with the Kürschner-Hoffer method, and the lowest with the currently preferred method described by Seifert (Prosiński 1984).

The total content of substances soluble in cold and hot water in the examined samples of silver birch wood $(0.84-2.77 \%)$ falls within the range of values 


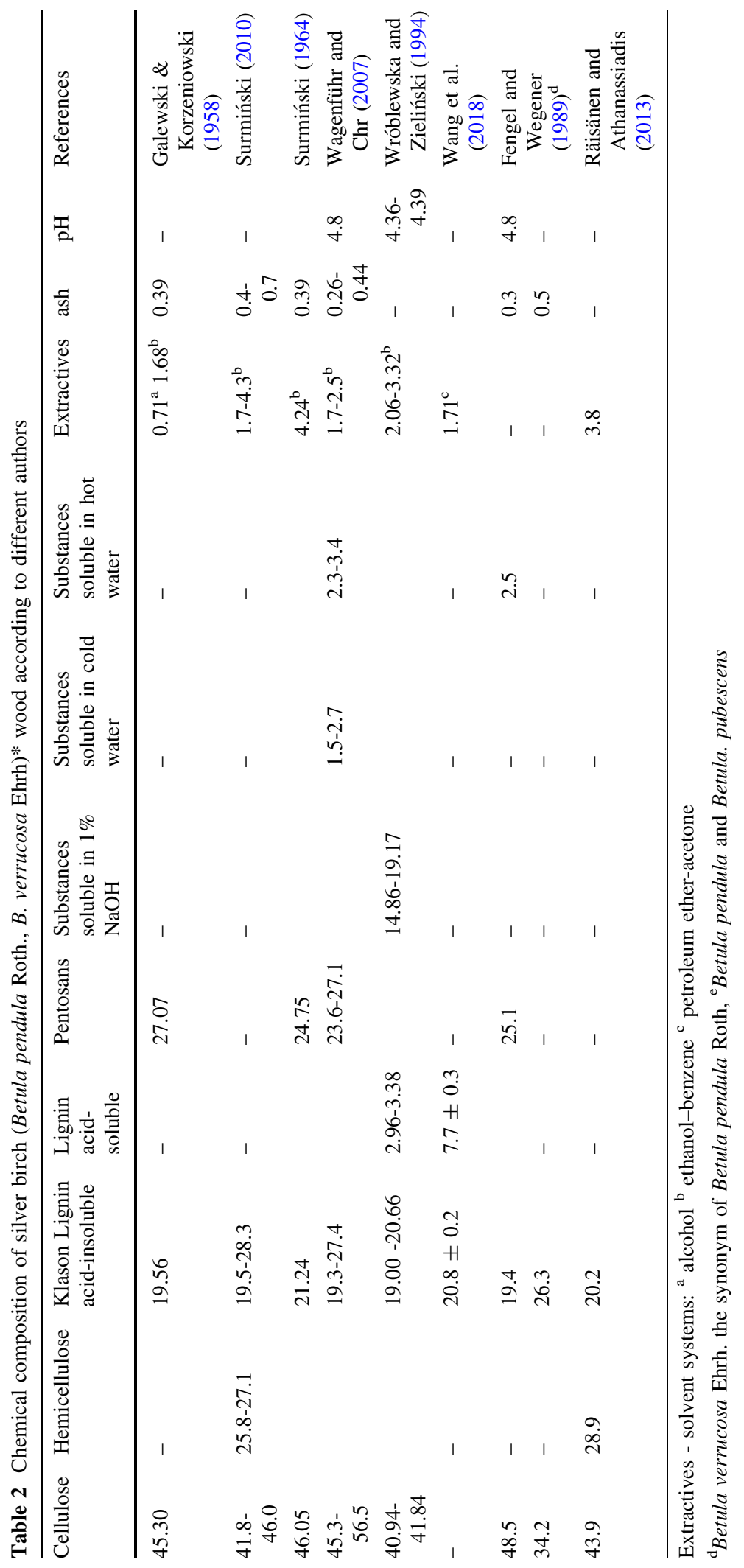




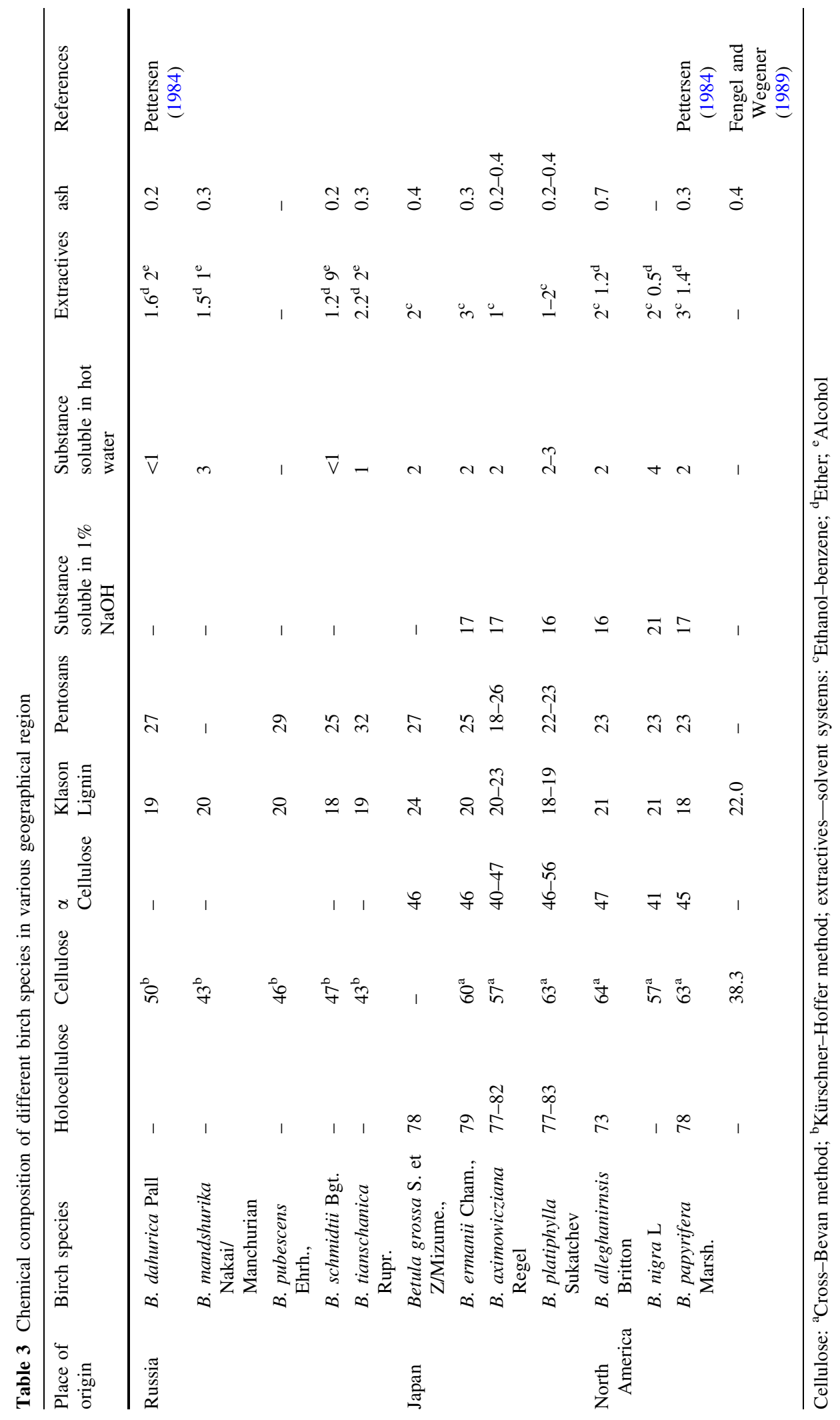


reported for birch species from different geographical regions, from less than 1 up to $4 \%$ (Table 2). However, it was lower than the values reported by Wagenführ and Scheiber (2007) for silver birch (2.3-3.4\%).

Ethanol, alongside ether, acetone, benzene, dichloroethane and methanol, is one of the organic solvents used in the determination of levels of extractives present in wood. For many years a mixture of ethanol and benzene $(1: 1$ or $1: 2)$ was used, but due to the carcinogenicity of benzene, this mixture was replaced by other solvents. It is clear that the results of the extraction process depend heavily on the solvents used (Yang and Jaakkola 2011). Therefore it is important to always give the solvent used in the test. Presented in this paper amount of substances soluble in ethanol was calculated according to PN-P-50092 (1992). The content of extractives in silver birch wood samples from the 17 test plots amounted to $1.15-1.99 \%$, which is also comparable to the published results concerning the extractives content (1.09-4.3\%) in Betula pendula wood samples presented in Table 2 as well as those reported by Pettersen (1984) (Table 3).

The content of substances soluble in $1 \% \mathrm{NaOH}$ in birch wood was found in this study to range from 14.16 to $16.28 \%$. In a study by Wróblewska and Zieliński (1994) birch wood was found to contain between $14.86 \%$ and $19.17 \%$ of such substances. In birch species from Japan, the United States and Russia, the content of substances soluble in $1 \% \mathrm{NaOH}$ ranged from 16 to $21 \%$ (Pettersen 1984).

The difference in the average cellulose content in Betula pendula birch from the 17 test plots, between the lowest value (41.78\%) and the highest (43.22\%), amounted to $1.44 \%$. The values obtained for individual locations are evenly spread throughout the entire country, and do not distinguish any groups of forest districts constituting birch resource bases (Fig. 6). The highest cellulose content was determined in the forest regions of Sokołów (FBF), Giżycko (FMBF), Rudziniec (FBF) and Biała Podlaska (FBF); these are the same locations in which the highest wood density values were recorded by Lachowicz (2015). Of particular note is the birch wood from Gorowo Iławeckie (FBF), which had the lowest cellulose content. The wood from this location had a belowaverage lignin content, the highest content of pentosans, substances soluble in $1 \% \mathrm{NaOH}$ and watersoluble substances, and a notable content of extractives. The cellulose content in silver birch wood reported by different authors ranged from 40.94 to $56.5 \%$ (Table 2). The average cellulose content in Betula pendula Roth. wood obtained in this study$42.65 \%$, falls in this range.

The average content of combined (acid-soluble and insoluble) lignin present in the wood of silver birch in all 17 test plots was $22.78 \%$. Klason lignin content in the tested samples ranged from 18.35 to $19.27 \%$ (averaging $18.78 \%$ ) and was comparable to the results reported by other authors (Tables 2,3). The content of soluble lignin ranged between 3.20 and $5.14 \%$ (averaging $4.00 \%$ ), was higher than the values given by Wróblewska and Zieliński (1994) (2.96-3.38\%).

The average pentosans content in silver birch wood for all test plots was $24.74 \%$, which is lower than the value of $27.07 \%$ given by Galewski and Korzeniowski (1958), but within the range of value reported by others authors for different birch species (Tables 2, 3).

The content of mineral substances in the tested samples of birch wood was low $(0.18 \%)$ compared with data available in the literature: $0.39 \%$ (Table 2). The wood of other birch species contained from 0.2 to $0.7 \%$ of mineral substances (Fengel and Wegener 1989; Pettersen 1984).

Silver birch wood is slightly acidic, as is the case with the majority of tree species growing in temperate zones. The average $\mathrm{pH}$ value of wood from all test plots was 4.62, which is higher than the value of 4.37 determined by Wróblewska and Zieliński (1994), but lower than the value of 4.8 given by Fengel and Wegener (1989) and by Wagenführ and Scheiber (2007) (Table 2).

The influence of the location of test plots on the chemical composition of silver birch wood from the 12 forest districts (17 test plots in total) distributed throughout the country proved to be minimal with regard to the primary components of wood, namely cellulose, pentosans and lignin. The sum of the contents of the principal wood components in individual locations ranged from $89.26 \%$ in Giżycko (FBF) up to $91.57 \%$ in Rudziniec (FMBF), the average being $90.15 \%$ (Fig. 12). The highest total content of cellulose, lignin and pentosans (above 91\%) was recorded in Rudziniec on both forest habitat types (FBF and FMBF). In Sokołów (FBF), Biała Podlaska (FBF), Giżycko (FMBF) and Lipinki (FBF), higher (above average for the whole group) contents of cellulose were determined together with lower (below average for the whole group) contents of lignin and 
Fig. 12 Contents of primary components of silver birch wood depending on test plot location

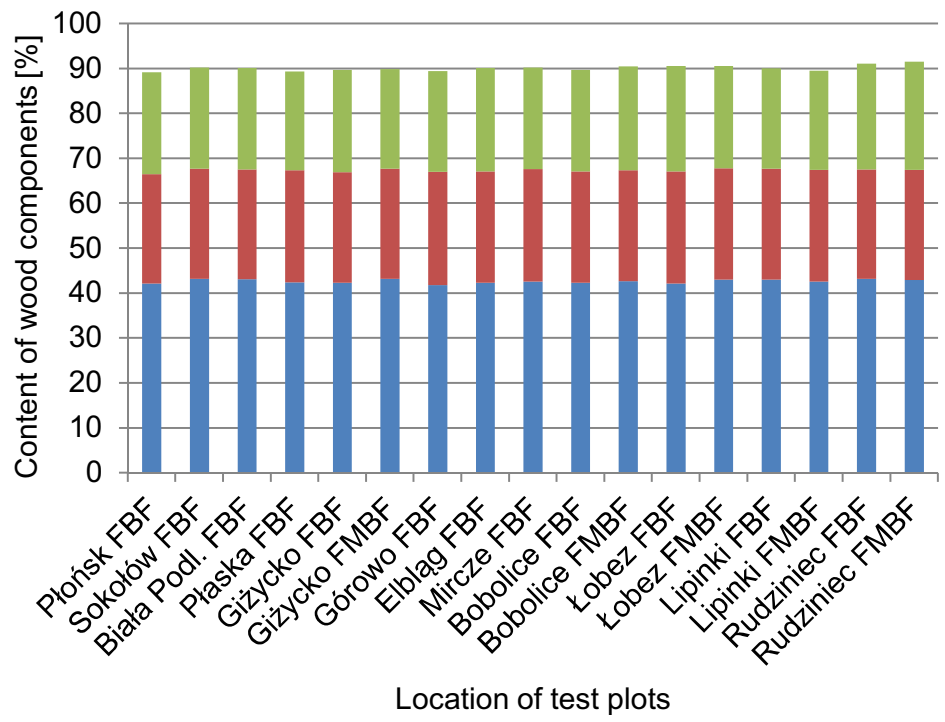

- Total Lignin

- Pentosans

- Cellulose pentosans. A higher than average content of pentosans was found in birch wood from Płaska (FBF), Górowo Iławeckie (FBF) and Bobolice (FBF), along with lower than average contents of cellulose and lignin. The wood from Płońsk (FBF), Elbląg (FBF), Mircze (FBF) and Łobez (FBF) had higher contents of lignin and pentosans than the average for the whole group, whilst the cellulose content was lower. Birch wood samples from the Łobez district, where the test plot was established on a fresh mixed broadleaved forest habitat, had cellulose, lignin and pentosans contents above the average values for the whole group, while in the wood from Giżycko (FMBF) the contents of all of these substances were below the average values for the whole group.

Unlike in the case of the primary components of wood, the influence of test plot location on the content of secondary constituents of birch wood, especially those extracted with water or ethanol, was significant. The total content of substances extracted with water or ethanol (combined) ranged between 2.30\% ( Lobez FBF) and $4.03 \%$ (Górowo Iławeckie FBF). In the five forest districts (Sokołów, Biała Podlaska, Płaska, Giżycko and Elbląg) located in the north-eastern part of Poland, birch wood from trees growing on an FBF habitat contained more extractives than wood from the other locations on FBF and FMBF habitats (Fig. 13). To show more clearly the slight differences in extractives (water and ethanol) content regardless of

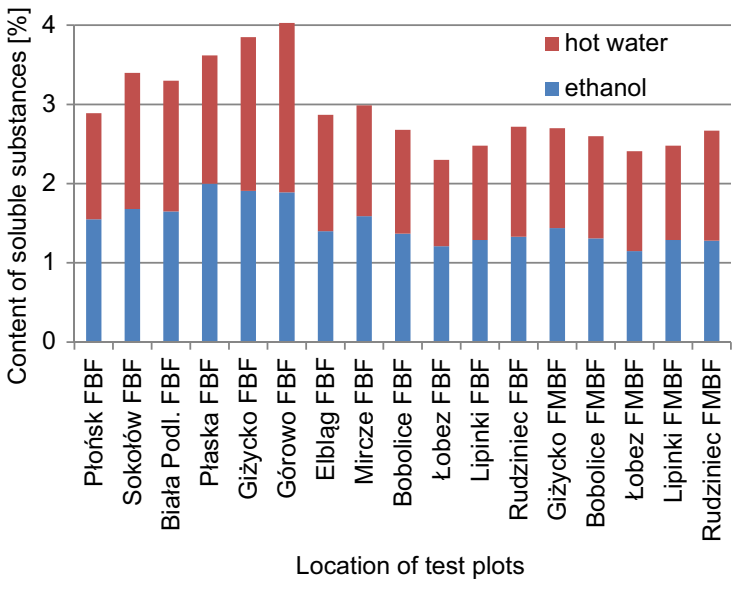

Fig. 13 Content of water and alcohol-soluble extractives in silver birch wood depending on test plot location

location, the five locations with the FMBF habitat type are placed on the right side of the graph (Fig. 13).

As concerns the chemical composition of wood, the pulp and paper industry is mostly interested in raw material with high cellulose content. Also, for fibreboard production, wood with high cellulose content is greatly valued, as it improves the mechanical and physical properties of the boards while low contents of lignin enhance the wood defibration process, making it more cost-effective (Surmiński 1979, 2010).

The abovementioned industry requirements are best met by birch wood originating from the forest districts of Sokołów (FBF), Giżycko (FMBF), Biała 
Podlaska (FBF), Lipinki (FBF), and Rudziniec (FBF and FMBF), despite the fact that wood from Rudziniec has a high lignin content. The high-cellulose wood from the locations listed also had the highest density (Lachowicz 2015; Lachowicz et al. 2018a).

The smallest amount of ash in birch wood was found in the forest district of Łobez (FBF and FMBF). Slightly higher ash content was recorded in wood from Płońsk (FBF), Lipinki (FMBF) and Rudziniec (FMBF). The lower the content of mineral components in the wood, the better it serves as a raw material for the production of wood-based boards, as a high ash content causes blunting of tools and makes drilling, milling, cutting and sanding processes more difficult.

Higher pentosans content was found in wood from the Płońsk (FBF), Płaska (FBF), Górowo Iławeckie (FBF), Mircze (FBF) and Łobez (FBF) forest districts, whereas a high content of extractives and watersoluble substances was observed in birch wood from the districts of Sokołów (FBF), Biała Podlaska (FBF), Płaska (FBF) and Giżycko (FBF) and Górowo Iławeckie (FBF). Thanks to these properties, the wood from the mentioned forest districts may serve as a biomass raw material for valuable added chemicals in different biorefining processes (Willför et al. 2005; Bergström and Matisons 2014).

The investigations of the chemical composition of silver birch (Betula pendula Roth.) wood from the 17 test plots established on two different forest habitat types (FBF and FMBF) in this study are closely aligned with the research work of many distinguished scientists working on possibilities of multidirectional utilization of all birch wood components. The aim is to examine the influence of the chemical composition of birch wood on its effective and waste-free use as a raw material not only in the pulp and paper industry, but also as a renewable resource-lignocellulosic biomass. In the latest study programmes concerning the structure of wood, emphasis is placed on a complete and accurate understanding of the chemical composition of the primary constituents (especially hemicelluloses and lignin) and of the secondary constituents (substances soluble in water and organic solvents) as well as their transformation under the influence of factors present during handling and processing (thermal, hydrolytic, enzymatic, chemical, mechanical, etc.). Thus research aims to optimise the traditional methods and to develop new ecological methods of birch wood utilisation that are compatible with sustainable development. Buzała et al. (2015) carried out studies on the susceptibility of cellulose pulp obtained using sulphate and thermomechanical methods and from wood chips of different tree species (including silver birch) to enzymatic decomposition all the way to glucose and reducing sugars. In the course of their research, they investigated the influence of lignin content on the enzymatic hydrolysis yields. The greatest amounts of glucose and reducing sugars were obtained from cellulose pulp that contained the smallest amount of lignin.

The wood of silver birch (Betula pendula Roth.), like that of many other deciduous trees, contains substantial quantities of hemicelluloses, which are partially soluble in water. During the production of pulp using a mechanical or chemical-mechanical method, water-soluble polysaccharides are released and accumulate in process waters. Anionic polysaccharides are particularly damaging and can react with cationic polymers used in paper production, causing precipitation of deposits (Willför et al. 2005). Because of this phenomenon, the aforementioned authors analysed sugar extracts obtained from 11 deciduous tree species including silver birch. It was found that birch wood contained the highest quantity of 4-Omethylglucuronic acids, which undergo transformation during the production processes of sulphate wood pulp. Silver birch wood contained $415 \mathrm{mg} / \mathrm{g}$ of cellulose (the results coincide with the findings presented in this study) and the highest amounts of xylan in comparison with the other species examined (Willför et al. 2005).

Comprehensive innovative utilization of birch wood in the future depends on obtaining knowledge on chemical reactions taking place between wood components during wood processing. In the literature, one can find in-depth research on the transformation of chemical constituents of birch wood by means of various technological processes. According to Kocaefe et al. (2008) the thermal processing of paper birch wood (Betula papyrifera) mainly caused the decomposition of hemicelluloses (responsible for the hygroscopicity of the wood), and to a lesser degree the ramification of lignin and crystallisation of the cellulose responsible for the mechanical properties of the wood. Under the influence of temperature, the wood changed colour from light to dark, quite possibly because the hemicelluloses separated into coloured substances and lignin changed its structure (it is a well- 
known fact that lignin reacts with electromagnetic waves in the visible range). Investigations of the discolouration of birch wood by vacuum drying proved that the change of colour is caused mainly by extractible phenolic compounds with low molecular weight (Hiltunen et al. 2008). Some of the 23 phenolic substances (glycosides), including three new ones, extracted from the wood of silver birch (Betula pendula Roth.) by Hiltunen et al. (2006) can be partially found in the bark of this tree species. The other phenolic extractives can be found in the wood of other birch species. Colour changes in birch wood caused by bleaching with an acidic solution of $\mathrm{H}_{2} \mathrm{O}_{2}$ indicate the breakdown of aromatic structures, with an apparent increase of unchanged carbonyl structures (Mononen et al. 2005).

The wood and bark of birch are the subject of detailed investigations and studies concerning new methods of biological treatments (biorefining, pyrolysis) having the aim of replacing synthetic chemicals with those obtained from renewable sources: furfural, bioethanol, etc. (Karnaouri et al. 2016; Turley et al. 2006; Vedrenikovs et al. 2010; Zhurinsh et al. 2013).

\section{Conclusions}

Analysis of the results obtained during the most extensive study to date in Poland concerning the variability in the chemical composition of silver birch (Betula pendula Roth.) wood depending on the forest habitat type and the location of forest stands leads to the following conclusions:

- Forest stand location has a statistically significant influence on all examined constituents of the chemical structure of silver birch wood. On the contrary, the forest habitat type has no statistically significant influence on the analysed parameters.

- The total content of the primary constituents of birch wood in individual locations ranged from $89.26 \%$ in wood from Giżycko (FBF) to $91.57 \%$ in samples from Rudziniec (FMBF), the average being $90.15 \%$. According to statistics the influence of location on the content of the main constituents of silver birch wood-cellulose, lignin and pentosans in the 12 studied forest districts was low.

- In the case of the test plots established in northeastern Poland, location has a clear influence on the content of secondary constituents of birch wood, especially substances extracted with water and ethanol.

- The study allows identifying locations where birch wood resources are of highest value for various industries. Wood from the forest districts of Sokołów (FBF), Giżycko (FMBF), Biała Podlaska (FBF) and Lipinki (FBF), due to the higher cellulose content and lower lignin content, has a potentially higher value for the pulp and paper industry as well as for fibreboard production.

- Comprehensive results and knowledge concerning the variability in the chemical composition of silver birch wood depending on the forest habitat type and the location of the forest stand, may have a meaningful impact on a more rational and economic use of this valuable wood, on the implementation of innovative wood application pathways as well as on the breeding selection. The results of this study should be a strong support tool in the construction of the marketing strategy of the State Forests in Poland.

Acknowledgments This work was supported by the General Directorate of State Forests in Poland (Grant No. EO-2717-13/ 13).

Open Access This article is distributed under the terms of the Creative Commons Attribution 4.0 International License (http:// creativecommons.org/licenses/by/4.0/), which permits unrestricted use, distribution, and reproduction in any medium, provided you give appropriate credit to the original author(s) and the source, provide a link to the Creative Commons license, and indicate if changes were made.

\section{References}

Bergström D, Matisons M (2014) Forest refine, 2012-2014efficient forest biomass supply chain management for biorefineries: synthesis report. Rapport från Institutionen för skogens biomaterial och teknologi, Umea. https://pub. epsilon.slu.se/11689/7/bergstrom_d_matisons_m_141208. pdf. Accessed 31 July 2018

Braun HJ (1963) Die Organisation des Stammes von Bäumen und Sträuchern. Wissenschaftliche Verlagsgesellschaft, Stuttgart

Browning BL (1967) Methods of wood chemistry. Interscience Publishers a Division of Wiley, New York

Bruchwald A (1989) Statystyka matematyczna dla leśników. SGGW, Warsaw 
Buzała K, Przybysz P, Rosicka-Kaczmarek J, Kalinowska H (2015) Comparison of digestibility of wood pulps produced by the sulfate and TMP methods and woodchips of various botanical origins and sizes. Cellulose 22:2737-2747. https://doi.org/10.1007/s10570-015-0644-9

Clark JH, Deswarte FEI (2008) Introduction to chemicals from biomass. Wiley, New York

Fengel D, Grosser D (1975) Chemische Zusammensetzung von Nadel-und Laubhölzern. Holz als Roh-und Werkstoff 33:32-34. https://link.springer.com/article/10.1007/ BF02612913. Accessed 31 July 2018

Fengel D, Wegener G (1989) Wood-chemistry, ultrastructure, reactions. Walter de Gruyter, Berlin

Galewski W, Korzeniowski A (1958) Atlas najważniejszych gatunków drewna. PWRiL, Warsaw

Gray VR (1958) The acidity of Wood. J Inst Wood Sci 1:58-64

Grochowski J (1973) Dendrometria. PWRiL, Warsaw

GUS (Central Statistical Office) (2016) Leśnictwo Forestry 2016. https://stat.gov.pl/en/topics/agriculture-forestry/ forestry/forestry-2016,1,7.html. Accessed 31 July 2018

Gustafsson C, Olinmaa PJ, Saarnio J (1952) The carbohydrates in birch wood. Acta Chem Scand 6:1299-1300. http:// actachemscand.org/pdf/acta_vol_06_p1299-1300.pdf. Accessed 31 July 2018

Hall JW (1952) The comparative anatomy and phylogeny of the Betulaceae. Bot Gaz 113(3):235-270

Han JS, Rowell JS (1997) Chemical composition of fibres. In: Rowell RM, Young RA, Rowell JK (eds) Paper and composites from agro-based resources, chap 5. Lewis Publishers, Boca Raton, New York, London, Tokyo, pp 83-134

Hansen NML, Blomfeldt TOJ, Hedenqvist MS, Plackett DV (2012) Properties of plasticized composite films prepared from nanofibrillated cellulose and birch wood xylan. Cellulose 19:2015-2031. https://doi.org/10.1007/s10570-0129764-7

Hillis WE (1962) Wood extractives. Academic Press, New York

Hiltunen E, Pakkanen TT, Alvila L (2006) Phenolic compounds in silver birch (Betula pendula Roth) wood. Holzforschung 60:519-527. https://doi.org/10.1515/HF.2006.086

Hiltunen E, Mononen K, Alvila L, Pakkanen TT (2008) Discolouration of birch wood: analysis of extractives from discoloured surface of vacuum-dried European white birch (Betula pubescens) board. Wood Sci Technol 42:103-115. https://doi.org/10.1007/s00226-007-0143-8

Huber B, Prütz G (1938) Über den Anteil von Fasern, Gefässen und Parenchym am Aufbau verschiedener hölzer. Holz als Roh-und Werkstoff 10:377-381. https://doi.org/10.1007/ BF02613180

Ibrahim RHH, Darvell LI, Jones JM, Williams A (2013) Physicochemical characterisation of torrefied biomass. J Anal Appl Pyrolysis 103:21-30. https://doi.org/10.1016/ j.jaap.2012.10.004

Kala R (2009) Statystyka dla przyrodników. Wydawnictwo Uniwersytetu Przyrodniczego w Poznaniu, Poznan

Karnaouri A, Rova U, Christakopoulos P (2016) Effect of different pretreatment methods on birch outer bark: new biorefinery routes. Molecules 21(4):427. https://doi.org/10. 3390/molecules21040427
Kocaefe D, Poncsak S, Boluk Y (2008) Effect of thermal treatment on the chemical composition and mechanical properties of birch and aspen. BioResources 3(2):517-537

Kociołek-Balawejder E, Żebrowska MK (2009) Brzoza - kierunki wykorzystania biomasy. Prace naukowe Uniwersytetu Ekonomicznego we Wrocławiu nr 57. Nauki Inżynierskie i Technologie 1:252-265

Krutul D, Zielenkiewicz T, Antaczak A, Zawadski J, Radomski A, Kupczyk M et al (2011) Influence of the environmental pollution on the chemical composition of bark and wood of trunk, branches and main roots of birch (Betula pendula Roth.). Ann Warsaw Univ Life Sci For Wood Technol 74:242-248. http://annals-wuls.sggw.pl/files/files/fwt/ fwt2011no74art45.pdf

Lachowicz H (2010a) Structure of silver birch wood fibers (Betula pendula Roth.) in north-eastern Poland. Leśne Prace Badawcze 71(1):39-50. https://doi.org/10.2478/ v10111-010-0002-5

Lachowicz H (2010b) Selected indicators of technical quality of silver birch (Betula pendula Roth.) wood in north-eastern Poland. Leśne Prace Badawcze 71(2):135-147. https://doi. org/10.2478/v10111-010-0010-5

Lachowicz H (2011a) Influence of location and age on the value of wood strength coefficients for silver birch (Betula pendula Roth.). Sylwan 155(8):535-545

Lachowicz H (2011b) Effect of tree thickness on the selected structural and physico-mechanical properties of silver birch (Betula pendula Roth.) wood. Sylwan 155(9):581-588

Lachowicz H (2015) Wieloczynnikowa analiza zmienności wybranych właściwości strukturalnych, fizycznych i mechanicznych drewna brzozy brodawkowatej (Betula pendula Roth.) Rozprawy Naukowe i Monografie. Wydawnictwo SGGW, Warsaw

Lachowicz H, Paschalis-Jakubowicz P (2011) Variability of the wood fibre structure indices for silver birch (Betula pendula Roth.) in north-eastern Poland. Sylwan 155(7):446-458

Lachowicz H, Wysocka-Fijorek E, Paschalis-Jakubowicz P (2016) Silver birch timber market in Poland in 2008-2012. Sylwan 160(12):971-980

Lachowicz H, Paschalis-Jakubowicz P, Wojtan R (2018a) Multivariate analysis of the variability in the density of oven-dry wood of silver birch (Betula pendula Roth.) in Poland. Drewno. https://doi.org/10.12841/wood.16443985.233.09

Lachowicz H, Sajdak M, Paschalis-Jakubowicz P, Cichy W, Wojtan R, Witczak M (2018b) the influence of location, tree age and forest habitat type on basic fuel properties of the wood of the silver birch (Betula pendula Roth.) in Poland. Bioenergy Res 11(3):638-651. https://doi.org/10. 1007/s12155-018-9926-z

Mononen K, Jaaskelainen A, Alvila L, Pakkanen T, Vuorinen T (2005) Chemical changes in silver birch (Betula pendula Roth) wood caused by hydrogen peroxide bleaching and monitored by color measurement (CIELab) and UV-Vis, FTIR and UVRR spectroscopy. Holzforschung 59:381-388. https://doi.org/10.1515/HF.2005.063

Murtagh F, Legendre P (2014) Ward's hierarchical agglomerative clustering method: Which algorithms implement ward's criterion? J Classif 31(3):274-295 
Nikitin NI (1962) Chimija drewiesiny i celljulozy. MoscowLeningrad, pp 512-513

Ozolinčius R, Bareika V, Rubinskienė M, Viškelis P, Mažeika R, Staugaitis G (2016) Chemical composition of silver birch (Betula pendula Roth.) and downy birch (Betula pubescens Ehrh.) Sap. Balt For 22(2):222-229

Pettersen RC (1984) The chemical composition of wood. In: Rowell RM (ed) The chemistry of solid wood. Advances in chemistry series 207. American Chemical Society, Washington, pp 57-126

Pinto PCRO, Sousa AF, Silvestre AJD, Neto CP, Gandini A, Eckerman C et al (2009) Quercus suber and Betula pendula outer barks as renewable sources of oleochemicals: a comparative study. Ind Crops Prod 29(1):126-132. https:// doi.org/10.1016/j.indcrop.2008.04.015

PN-P-50092 (1992) Surowce dla przemysłu papierniczego. Drewno. Analiza Chemiczna

Prosiński S (1984) Chemia drewna. PWRiL, Warsaw

Prosiński S, Kontek W, Babicki R (1955) Skład chemiczny drewna świerkowego w zależności od wieku drzew i zasięgu naturalnego. Prace Instytutu Technologii Drewna Rok I, Z. 1:5-22

Rabemanolontsoa H, Saka S (2013) Comparative study on chemical composition of various biomass species. RSC Adv 3(12):3946-3956

Räisänen T, Athanassiadis D (2013) Basic chemical composition of the biomass components of pine, spruce and birch. For Refine 31:4

Surewicz W (1972) Ocena drewna brzozy jako surowca do wyrobu mas celulozowych. Conference proceedings: Drewno liściaste jako surowiec celulozowo-papierniczy. Lodz 26.01.1972

Surmiński J (1964) Skład chemiczny tkanek patologicznych drzewnych narośli rakowatych. Rocznik dendrologiczny 18:63-77

Surmiński J (1979) Właściwości techniczne drewna brzozy i możliwości jego użytkowania. (W:) Brzozy. PWN, Warszawa-Poznań

Surmiński J (2010) Zarys chemii drewna. AR, Poznan

Süss H (1967) Über die Längenänderungen der Parenchymstränge, Holzfasern und Gefässglieder von Laubhölzern im Verlauf einer Zuwachsperiode. Holz als Roh-und Werkstoff 25:369-377

Süss H, Müller-Stoll WR (1969) Über das Faserwachstum, seine Beziehungen zum jahresperiodischen Dickenwachstum und die Faserüberlappung bei einigen Laubhölzern.
Holzforschung 23(5):145-152. https://doi.org/10.1515/ hfsg.1969.23.5.145

TAPPI, Standards Technical Association of Pulp and Paper Industry (1996-1997), 360 Lexington AM, New York 17

Testova L, Vilonen K, Pynnönen H, Tenkanen M, Sixta H (2009) Isolation of hemicelluloses from birch wood: distribution of wood components and preliminary trials in dehydration of hemicelluloses. Lenzinger Berichte 87:58-65

Turley DB, Chaudhry Q, Watkins RW, Clark JH, Deswarte FEI (2006) Chemical products from temperate forest tree species-developing strategies for exploitation. Ind Crops Prod 24(3):238-243. https://doi.org/10.1016/j.indcrop. 2006.06.016

Vedrenikovs N, Kampars V, Puke M, Kruma I (2010) Changes in the birch wood lignocelluloses composition in the pretreatment process. Sci J Riga Tech Univ Mater Sci Appl Chem 22:68-73

Wagenführ R, Scheiber C (2007) Holzatlas. VEB Fachbuchverlag, Leipzig

Wang Z, Winestrand S, Gillgren T, Jönsson LJ (2018) Chemical and structural factors influencing enzymatic saccharification of wood from aspen, birch and spruce. Biomass Bioenergy 106:125-134

Willför S, Sundberg A, Pranovich A, Holmbom B (2005) Polysaccharides in some industrially important hardwood species. Wood Sci Tehnol 39(8):601-617. https://doi.org/ 10.1007/s00226-005-0039-4

Wolski J (1969) Pierśnica - reprezentatywną cechą do wyboru drzew próbnych przy oznaczaniu fizycznych i mechanicznych właściwości drewna. Sylwan 113(8):77-78

Wróblewska H, Zieliński MH (1994) Biodelignifikacja drewna pod wpływem działania grzybów rozkładu białego. Instytut Technologii Drewna, Poznan

Yang G, Jaakkola P (2011) Wood chemistry and isolation of extractives from wood. Literature study for BIOTULI project, Saimaa University of Applied Sciences

Zhurinsh A, Dobele G, Rizhikovs J, Zandersons J, Grigus K (2013) Effect of pre-treatment conditions on the analytical pyrolysis products from birch wood lignocelluloses. J Anal Appl Pyrolysis 103:227-231. https://doi.org/10.1016/j. jaap.2012.12.008

Publisher's Note Springer Nature remains neutral with regard to jurisdictional claims in published maps and institutional affiliations. 